\title{
COVID-19: PANDEMIC OF DOMESTIC VIOLENCE
}

COVID-19: PANDEMIA DE VIOLENCIA DOMÉSTICA

\author{
Tatiana Stoianova* \\ Liudmyla Ostrovska** \\ Grygorii Tripulskyir ${ }^{* * *}$
}

\begin{abstract}
The article is devoted to the analysis of domestic violence in the context of Covid-19. The research is carried out for the first time in the focus of several sciences: psychology, sociology, and jurisprudence. To study the legal regulation of domestic violence, knowledge from different branches of law was used: international, criminal, administrative, and civil procedural law. Attention was paid to the historical retrospective-how the concept of domestic violence first appeared at the world level, and how it was differentiated and implemented in the national legislation of the participating countries. The problems of signing the Istanbul Agreement are highlighted. Special attention was paid to the current wave of domestic violence as a result of the Covid-19 pandemic. The prerequisites of a general psychological, social, and economic nature, their interdependence, and connection with the pandemic were investigated. The scale of the scourge of domestic violence in the context of a pandemic in different countries is indicated, and its short-term and long-term consequences for the well-being of the nation. The specific mechanisms for preventing family violence at
\end{abstract}

\footnotetext{
* Ph. D., Associate Professor of Department of Civil Procedure of National University «Odesa Law Academy» (Odesa, Ukraine). https://orcid.org/0000-0002-9696-6701. stoyanova_t_a@online.ua

** Ph. D., Associate Professor of Department of Civil Procedure of National University «Odesa Law Academy» (Odesa, Ukraine). https://orcid.org/0000-0003-4946-4044. freebee28@gmail.com

** Ph. D., Associate Professor of Department of Civil Procedure of National University «Odesa Law Academy» (Odesa, Ukraine). https://orcid.org/0000-0003-2251-497X. tripulskyy@gmail.com
} 
three levels are considered: general criminogenic, a comprehensive mechanism for preventing violence at the level of interaction between the state and public organizations, and directly special means. The study concludes that Covid-19 pandemic has a direct impact on the exacerbation of domestic violence. The solutions are proposed, from legislative amendments to the redistribution of state and public forces to address the problem of domestic violence.

Keywords: Domestic Violence, Restraining Order, Covid-19, Selfisolation, Quarantine

Resumen: El artículo analiza la violencia doméstica en el contexto del Covid-19. La investigación se lleva a cabo por primera vez en el enfoque de varias ciencias: psicología, sociología y jurisprudencia. Para el estudio de la regulación legal de la violencia intrafamiliar se utilizaron conocimientos de diferentes ramas del derecho: derecho internacional, penal, administrativo y procesal civil. Se prestó atención a la retrospectiva histórica: cómo apareció por primera vez el concepto de violencia doméstica a nivel mundial y cómo fue diferenciado e implementado en la legislación nacional de los países participantes. Se destacan los problemas de la firma del Acuerdo de Estambul y a la ola actual de violencia doméstica que ha resultado por la pandemia Covid-19. Se investigaron los requisitos previos de naturaleza psicológica, social y económica general, su interdependencia y conexión con la pandemia, indicando la magnitud del flagelo de la violencia doméstica en diferentes países y sus consecuencias a corto y largo plazo para el bienestar general. Se consideran los mecanismos específicos de prevención de la violencia intrafamiliar en tres niveles: criminógeno general, mecanismo integral de prevención de la violencia donde interactúan el Estado y las organizaciones públicas, y otros medios directamente especiales. El estudio concluye que la pandemia de Covid-19 tiene un impacto directo en la exacerbación de la violencia doméstica. Se proponen las soluciones, desde enmiendas legislativas hasta la redistribución de fuerzas estatales y públicas para abordar el problema de la violencia doméstica.

Palabras clave: Violencia doméstica, orden de restricción, Covid-19, autoaislamiento, cuarentena

Summary. I. Introduction. II. Methodology. III. Analysis of recent research. IV. Results and discussion. IV.1. International and National Legal Doctrine to Prevent Domestic Violence by the Time of the Covid-19 Pandemic. IV.2. Exacerbation of 
Domestic Violence during the Covid-19 Pandemic and Its Consequences. a) General. b) Impact on Children. c) Social and Economic Impact. IV.3. Common Causes of Domestic Violence and Ways to Address Them. IV.4. Special measures to prevent domestic violence and recommendations for their improvement. a) Taking the Offender on Preventive Records and Carrying Out Preventive Work with Him. b) Sending the Abuser to a Program for Perpetrators. c) Urgent Injunction Against the Abuser. d) Restrictive Injunction against the Offender. V. Conclusions. References.

\section{INTRODUCTION}

Violence is one of the most common forms of violation of the fundamental human rights of life and health. Typically, women, children and the elderly suffer the most from violence. Domestic violence is the most common and most difficult to deal with. Domestic violence is inherent in many states, despite their positive achievements in the legislative, political, and practical spheres.

According to statistics that were released in 2017 during the voting for the Law of Ukraine "On Preventing and Countering Domestic Violence" (2017), more than 3 million children in Ukraine annually observe acts of domestic violence or are their forced participants, and almost $70 \%$ of women at least once in a lifetime are exposed to various forms of bullying and humiliation. About 1,500 women die each year at the hands of their husbands, a trend that has increased over the past three years (Guidelines for preventing and combating violence, 2018).

The sluggish armed conflict in the east of the country that has been going on for 6 years, the ongoing economic recession, and now the Covid19 pandemic and related restrictive measures have aggravated the crime situation so much that in 2020 Ukraine became the most dangerous country in Europe and occupies a leading position in the world in the level of violence and crime (Numbeo, Crime Index by Country 2020 Mid-Year, 2020).

From the rostrum of the United Nations (UN), words are heard about a pandemic of violence in the world in the context of quarantine measures, self-isolation, job loss, and the general psychologically unhealthy state of the population around the world. We will try to understand the problem of domestic violence in Ukraine and give clear and intelligible recommendations "here and now" to the government and public organizations on how to help people who have suffered from domestic violence.

To reach the goal of the study, let's outline the following structure of work. In the first section, we will consider international and national legislation, assess how it corresponds to today's realities, what flaws it 
contains, and how they can be corrected. In the second section, we will identify the connection between the pandemic and the exacerbation of domestic violence around the world and predict its consequences. In the third section, we will examine the common causes of domestic violence and ways to address them. In the fourth section, we will explore special measures to prevent domestic violence and give recommendations for their improvement.

\section{Methodology}

The dialectical method was used to consider and study the unity of the causes and consequences of the emergence of domestic violence and its exacerbation during the forced self-isolation of Covid-19 (section IV, subsections 2, 3).

Besides, the systemic and structural method made it possible to study state policy in the field of protecting women, children and other subjects from domestic violence, through researching a newly introduced mechanism for creating special government bodies, reorganizing the function of already existing bodies and endowing the legal foundations of educational activities to form legal awareness in this area of educational institutions, public organizations (section IV, subsections 3, 4).

More than that, the use of statistical method contributed to the generalization of legal practice, the analysis of empirical information related to the research topic (section IV, subsections 2, 3).

The historical and legal method was used to study the stages of development of legislation regulating violence: from the first steps to consolidate this concept, as the right of every person to live without violence, to the adoption of specific, differentiated international acts (section IV, subsection 1).

At the same time, the comparative legal method was used during the study of legal literature, analysis of legislation in the process of studying its relationship with similar norms of international legislation (subsection 1).

The formal legal method was applied during the study of the legal sources of scientific work, which made it possible to reveal the shortcomings of the current legislation of Ukraine, which regulates the activities of subjects in the field of protecting women, children and other subjects from violence and to formulate proposals for improving their activities (section IV, subsection 3, 4).

Eventually, these methods, in their interconnection, based on logical methods and techniques (analysis, synthesis, induction, deduction, analogy), 
made it possible to comprehensively and effectively investigate such a phenomenon as domestic violence in the specific conditions of a pandemic and the current development of the domestic public institution to counter domestic violence.

\section{ANALYSIS OF RECENT RESEARCH}

Even though the problem of domestic violence has existed for as long as civilization has existed, it is quite young as an area of legal regulation. And, if the European Union (EU) countries and the United States have been studying this problem since the 60s of the 20th century, Ukraine has actively begun to deal with this issue quite recently within the framework of the implementation of international law and harmonization of legislation after signing an association with the EU.

To date, among domestic scholars, one can single out Tomusyakova (2014), Yavoroska (2020), Kaczynska (2016), and Bugaets (2019). Most of their scientific works are related to the criminal or administrative aspects of the legal regulation of domestic violence.

It should be noted that many scholars have dealt with the problems of domestic violence in the context of violence against children. This tradition takes its roots from the Soviet past of a country where children were given particular scrupulous attention within the framework of a socialist society. So among the dissertations of the last period in Ukraine, it is especially worth noting the work of Tkalenko (2016) on the topic "Administrative and legal regulation ensuring the activities of public administration bodies to prevent domestic violence against children". This work reveals the scope of activities of administrative bodies, which are entrusted with the function of a mechanism for preventing domestic violence against children. The work of Lesko (2019), on the topic: "Administrative and legal support for the formation and implementation of state policy in the field of protecting children from violence and other illegal actions" at a more doctrinal level and with taking into account the new paradigm of domestic violence, reveals the newly introduced mechanism for preventing and combating domestic violence. Outside the topic of administrative bodies responsible for the implementation of the mechanism for countering domestic violence, one can cite as an example Romantseva's (2018) "Prevention of sexual violence against children in Ukraine." This work reveals the criminal law aspect of violence against children.

The work of Osipyan (2012), Timko and Kuznetsova (2017) also deserves mention. They separately consider domestic violence on the part of 
women, its psychological specifics and the complexity of the work of law enforcement agencies due to the high latency and cultural stereotypes of men themselves, who do not consider it necessary to seek help because this will "disgrace them even more."

In light of the recent events of the Covid-19 pandemic, many foreign scholars and experts are sounding the alarm about a wave of domestic violence in different countries and are trying to find the cause of this phenomenon. Among them are: Johnson (2020), Abueish (2020), Wanqing (2020), Burgen (2020), Janetsky (2020).

However, there is no comprehensive approach to the study of domestic violence and not individual aspects of its regulation among dissertations. Considering the exacerbation of the problem of domestic violence during the pandemic and the ongoing process of developing law enforcement practice and judicial experience, there is still a lot of work for the scholars.

\section{RESULTS AND DISCUSSION}

\section{IV.1. International and National Legal Doctrine to Prevent Domestic Violence by the Time of the Covid-19 Pandemic}

The first document that indirectly designated the right to a life without violence is the Universal Declaration of Human Rights, adopted by the United Nations General Assembly in 1948. According to Art. 1 "People have the right to live without violence. All people are born free and equal in their dignity and rights", According to Art. 5 "No one should be subjected to torture or cruel, inhuman or degrading treatment or punishment." This norm only outlined in general terms the inadmissibility of violence, nevertheless, this is the first step, at the global level, as the basis for the prevention of violence. It should be emphasized that the preconditions for such a step were the entire horror of the Second World War. That is, we can conclude that the growth of humanity, and hence its development, maturation occurs through certain "cataclysms". To some extent, this can be traced now, as a cataclysm in the form of quarantine and an increase in the level of domestic violence around the world - pushing humanity to pay attention to the need for the next steps in the development of mechanisms for ensuring the rights and freedom of every person.

The next step (in a historical reversal) in the legal regulation of violence was the adoption in 1993 by the United Nations of the Declaration on the Elimination of Violence against Women, which deals with the complete elimination of all forms of violence against women in various spheres of society: family, at work, in the whole state. 
In 1996, the United Nations developed guidelines for all countries through model legislation to combat domestic violence. This legislative act became the basis for the entire legal regulation of this issue. So, according to Tomusyakova (2014):

«The model legislation was created to improve the legislative framework of individual countries on combating domestic violence, they define the concept of domestic violence and define its forms, explain in detail the mechanism for submitting complaints by victims, define the rights of victims, the responsibilities of structures competent in family violence, and also established measures of emergency and planned assistance to victims who suffered from this brutal phenomenon».

Of the latest documents, interesting, both in terms of the content itself and in terms of the reaction of countries to its signing and implementation, is the so-called Istanbul Convention. The full title of the document is the Council of Europe Convention on Preventing and Combating Violence against Women and Domestic Violence, open for signature since May 2011 in Istanbul (hereinafter, the Istanbul Convention). With this international act, the Council of Europe paves the way for creating a legal and regulatory framework at the European level to protect women from all forms of violence, and to prevent, prosecute and eliminate violence against women and domestic violence. In addition, the Convention establishes a special monitoring mechanism ("Grevio") to ensure the effective implementation of its provisions by ratifying parties (Council of Europe, 2011). Article 3 of the Convention recognizes violence against women as a violation of human rights and a form of discrimination against women, which includes "all acts of gender-based violence that result or may lead to physical, sexual, psychological or economic harm or suffering for women, including threats to commit such acts, coercion or arbitrary deprivation of liberty, whether in public or private life." Besides, "gender-based violence against women" means "violence directed against a woman because she is a woman or affects women disproportionately".

However, not all states have responded positively to the adoption of this regulatory legal act. So, for example, in Armenia, this document caused a clash of opinions and the collection of signatures against ratification, based on the opinion that the adoption of the Convention will lead to "the creation of same-sex families and adoption by same-sex couples of children, and men who perceive themselves as women will be exempt from military service, which will reduce the fighting efficiency of the Armenian army (Areshev, 2019). In Bulgaria, the Convention was sharply criticized, a psychiatrist, theologian, and a former deputy spoke openly: "The Istanbul Convention is 
a suitcase with a "double bottom", and the term "gender" was described as "a word-chameleon" (Alekseeva, 2018). As a result, the Istanbul Convention was signed in Bulgaria but was not ratified due to popular resistance. Russia, being a member of the Council of Europe, also reacted negatively to the adoption of such an act and still refrains from signing it. In Latvia, the public discussion of the document gave rise to "a flurry of emotions in society" (Istanbul Convention: what is written in the controversial document, 2016). At the same time, the signing in the countries of Western Europe took place as usual. This contrast is due to more conservative attitudes, the dominance of patriarchal culture, and the strong role of religion in society.

Concerning Ukraine, it should be noted that the Convention was signed on November 7, 2011, but was never ratified. Only after the events of the pandemic, the side effect of which was a sharp increase in cases of domestic violence, a new impetus for the ratification of the Convention in Ukraine was the appeal of the United Nations to the Verkhovna Rada of Ukraine: "Violence against women and girls is not only a violation of human rights; it destroys lives and families across the country. In Ukraine, women make up $78 \%$ of victims of domestic violence" (UN calls on the Verkhovna Rada to ratify the Istanbul Convention, 2020).

The reasons for the lack of ratification so far can be identified as follows:

- Lack of political will and opposition from conservative political circles who see this as a threat to their influence;

- Low public awareness of the problem of domestic violence and possible ways of solving it, the specific benefits of ratification; and,

- The problem of aligning national legislation and law enforcement.

Let us dwell in more detail on the last point, because it falls into the sphere of our interests.

The Law on Prevention of Domestic Violence has been in force since 2001. In 2003, an article 173-2, which provides for administrative liability for psychological, economic, and physical (which did not cause bodily harm) violence, was included in the Code of Administrative Offenses (1984). If sexual violence has taken place, both before and now there is criminal liability under the Criminal Code of Ukraine (2001).

But in 2017, a new law "On the Prevention and Counteraction to Domestic Violence" was adopted, which was largely based on the latest international developments, and in particular on the Istanbul Convention (2011). On its basis, Article 126 "Domestic Violence" and Article 151 "Coercion to Marry" have been introduced into the Criminal Code of Ukraine (2001). It also offers a completely updated section on special measures to prevent violence, which we will discuss later. 
As a result, the law is quite progressive and comprehensive, but there are some shortcomings. The inconsistency of by-laws and departmental instructions, the still prevailing stereotypes among police officers, leads to poor quality of law enforcement by both law enforcement agencies and NGOs, as well as by victims who cannot overcome the grindstones of the bureaucratic machine.

Further, the Minister of Social Policy confirmed the sad statistics of recent years. In 2019, more than 130 thousand citizens' appeals were recorded about domestic violence, which is $15 \%$ more compared to the same period last year, of which $88 \%$ were from women, $10 \%$ were from men, and $2 \%$ from children (Skolovskaya, 2020).

However, according to Olena Strizhak of Positive Women, the United Nations Development Program compiled data, the situation is even worse. Only $10 \%$ of the victims go to the police, which means that the number of victims is well over a million. Separately, it is worth noting that the less helpless a person is, the higher his chance of becoming a victim of violence, for example, a VIL-infected woman has almost 2 times more chances of becoming a victim of domestic violence and in $47 \%$ of such cases, she has no one who can help.

Thus, the adoption of the law itself, as expected, did not correct the situation. Some problems of law implementation will be considered in the section on special measures of restraint, and as for the international legal framework and experience, Ukraine is in a rather advantageous position, as much work has already been done to analyze domestic violence and develop deterrents and rehabilitative mechanisms. The scientists must concentrate their attention to the implementation and adaptation of international experience to domestic conditions, to further fully ratify the Istanbul Convention.

\section{IV.2. Exacerbation of Domestic Violence during the Covid-19 Pandemic and Its Consequences}

Domestic violence is an intentional act of physical, sexual, psychological, or economic orientation of one family member towards another family member if these actions violate the constitutional rights and freedoms of a family member as a person and a citizen and cause him moral harm, harm to his physical or mental health.

The following are mandatory signs of domestic violence:

(i) persons suffering from domestic violence can only be family members (for example, this Law does not apply to neighbors, cohabitants, 
including divorced persons who continue to live together, persons who meet but are not married, etc.);

(ii) the act of the rapist must be illegal (for example, contrary to current legislation);

(iii) the act has led or could lead to a violation of the rights of a family member as a person and citizen; and,

(iv) the guilt of the abuser should be manifested in the form of intent, not negligence.

During the coronavirus pandemic in 2019-2020, many countries reported an exacerbation of domestic and partner violence. UN SecretaryGeneral Antonio Guterres, noting the "terrible global outbreak of violence", called for a "ceasefire" in households (UN chief calls for domestic violence "ceasefire" amid "horrifying global surge", 2020).

The pandemic, financial insecurity, stress, and insecurity have led to increased aggression, as has been the case in the past with the global financial crisis of 2008-2009 or natural disasters such as the 2011 Christchurch earthquake (Johnson, 2020).

Domestic violence is also more common when families spend more time together, such as during the Christmas holidays, as the frequency and severity of violence depends on the ability of perpetrators to control their victims in their daily lives over a long period. Therefore, the main impact of the pandemic is related to government measures known as lockdown, restriction of contact, and movement, aimed at slowing the spread of infection. According to French official Marlene Schiappa, "closure is an ideal environment for the rise of domestic violence (Abueish, 2020).

The first strange thing to face such consequences of the pandemic was China. Thus, the number of reports of domestic violence in February 2020 increased by $300 \%$ compared to February 2019. Local law enforcement officials are reluctant to report that $90 \%$ of the causes of violence are in one way or another related to the epidemic, restrictive measures, and their consequences (Wanqing, 2020).

In Spain (one of the first European countries to be hit by the pandemic) the Domestic Violence Help Line reported a 47\% increase in the first two weeks of April compared to the same period in 2019, while the number of women seeking services support via email or social media increased by $700 \%$. However, there was a simultaneous sharp drop in similar calls to the police. Officials and activists attribute this to the fact that now the victims are much more dependent on their offenders and isolated from their families and others who could support them (Burgen, 2020).

In Colombia, the mayor of the city of Bogota said that in the first week of quarantine, the only indicator in statistics, which did not decrease but 
increased by as much as $225 \%$ is domestic violence (Janetsky, 2020). Similar data is given by the vice-president of the country Marta Lucia Ramirez. She said that the number of calls to a special hotline " 155 " for victims of domestic violence has increased by 150 percent compared to the same period last year. President Ivan Duque promptly ordered the provision of basic resources to women and children facing domestic violence, but it was soon discovered that 590 Colombian police stations lacked basic infrastructures such as the Internet or an additional phone to receive calls about domestic violence, not to mention already about any medication or food for victims of violence. Colombia turned out to be completely unprepared for the aggravation of this negative phenomenon (Lauvergnier, 2020).

Thus, we see that the whole world has been swept by a wave of domestic violence, and only on how developed the institution of counteraction to such a phenomenon is in states depends on how much rights can be observed and people's lives saved.

Concerning Ukraine, traditionally, this phenomenon is reflected in the statistical data of the structural units of the Ministry of Internal Affairs, international missions, and national public organizations. So, if in 2018 the Ministry of Internal Affairs registered 110,932 reports of domestic violence, in 2019 - 141,814 reports, then only in the first six months of 2020, the UN Population Fund in Ukraine reported an increase in applications by $37 \%$, the public organization "La Strada - Ukraine" by 45\% (Yavoroska, 2020). Thus, by the end of the year, the total number of statements may approach 200,000, which will be a terrible anti-record for Ukrainian public life and thousands of maimed lives.

Separately, it should be noted that the phenomenon of domestic violence in our society has a high degree of latency and secrecy. Established traditions and stereotypes regarding domestic violence, as a closed, family case, should not be brought into the scope of public discussion and response as long as they prevent victims of violence from complaining to the police. Thus, most cases of violence remain unrecorded. The data of various studies and sociological assessments show that only in 10-20 percent of cases victims turn to law enforcement agencies (Kaczynska, 2016).

The latency of domestic violence is also related to the current level of inappropriate response by law enforcement agencies. Complaints of victims of domestic violence, testimonies of police officers themselves, and expert data show that the so-called "domestic offenses" are reluctant to go to the police. Many cases of domestic violence are still classified under the articles of the Administrative Code, including art. 173 "hooliganism". There are many cases when victims, having learned that the type of administrative penalty imposed on the violator will be a fine that will have to be paid by 
the victims themselves, withdraw their statements about the facts of domestic violence.

The consequences of domestic violence and its characteristics during the Covid-19 pandemic. According to a World Health Organization fact sheet, violence leads to serious short-term and long-term physical, mental, sexual, and reproductive health problems in women as the most frequent victims. These forms of violence also affect their children and generate significant social and economic costs for women, their families, and society.

Such violence can have the following consequences:

\section{a) General}

- It can be fatal in the form of homicide and suicide.

- It can be traumatic: $42 \%$ of women who have experienced intimate partner violence report trauma as a result of such violence.

- Such violence can result in unwanted pregnancy, induced abortion, gynecological problems, and sexually acquired infections, including HIV . These women are also statistically twice as likely to have an abortion.

- Intimate partner violence during pregnancy also increases the risk of miscarriage, stillbirth, premature birth, and low birth weight. According to the World Health Organization observation, women who have experienced intimate partner violence have a $16 \%$ increase in the likelihood of miscarriage and a $41 \%$ increase in the likelihood of premature birth.

- These forms of violence can lead to depression, Post-traumatic stress disorder (PTSD), and other anxiety disorders, sleep problems, eating disorders, and suicide attempts.

- Other health consequences may also include headache, back pain, abdominal pain, gastrointestinal upset, limited mobility, and weak general health.

- Sexual abuse, especially during childhood, can increase the likelihood of smoking, drug and alcohol abuse, and risky sexual behavior later in life. It also correlates with the perpetration of violence (for men) and exposure to violence as a victim (for women).

\section{b) Impact on Children}

- Children growing up in abusive families can suffer from a range of behavioral and emotional disorders that can lead to or be exposed to violence in later life.

- Intimate partner violence is also associated with increased rates of mortality and morbidity in infants and young children. 
c) Social and Economic Impact

- The social and economic costs of partner violence and sexual violence are enormous and have a range of long-term consequences for society. Women may suffer from isolation, inability to work, loss of earnings, lack of participation in normal activities, and limited ability to care for themselves and their children.

Thus, in difficult conditions of a pandemic, an economic recession, and mass unemployment, a wave of domestic violence is both a consequence of a pandemic and restrictive measures and that last straw before the final moral and physical decline, alcoholism and a wave of suicides of tens of thousands of people around the world.

The consequences of insufficient attention on the part of the state and society to the problems of domestic violence can be extremely deplorable, since it is a catalyst for many socially dangerous phenomena such as alcoholism, drug addiction, an increase in the level of crime, especially children, legal nihilism in society, degradation of the institution of the family, critically low fertility rate, etc.

\section{IV.3. Common Causes of Domestic Violence and Ways to Address Them}

It is now necessary to consider the most common causes and factors of domestic violence, the impact of pandemics and quarantine on them, and, accordingly, possible social measures to prevent domestic violence.

The first is external stress. Violence is closely linked to social stress in the family and society. Among the variety of problems that can increase tensions and lead to violence are:

- difficult financial situation, financial difficulties in the family;

- unemployment or unsatisfactory working conditions;

- the need for long-term or expensive medical care;

- unsatisfactory living conditions, living in conditions that violate sanitary and epidemiological norms; and,

- lack of social assistance from the state, public organizations, a sense of abandonment.

Given the variety of causes of stress, it is difficult to develop a "universal recipe", but due to many of these problems permeate one main, namely the economic well-being of Ukrainian families. The permanent economic crisis and social upheavals since 2014 and now the economic quarantine due to the pandemic have not contributed to the economic wellbeing of the population. Thus, according to the United Nations, more than 80 percent of Ukrainians live below the poverty line, and the subsistence 
level in Ukraine is approaching the poverty line of African countries. And, in this situation, the domestic legislator in the State Targeted Social Program of Family Support 2016-2020 concludes that material support for families is "an ineffective means of state support", and reduces several times childbirth benefits, benefits for young families, etc. (About the statement of the State target social program, 2016).

This position of the authorities is understandable because the budget has limited funds and in general there are more pressing problems, such as the very survival of the Ukrainian state. Nevertheless, the material stimulation and overcoming of the socio-economic crisis is the only basis on which the development of the institution of the family and a peaceful life of Ukrainian families without violence is possible.

The second factor is social and psychological decompensation as a result of external influences that exceed the limits of the personal resilience of individuals. These include situations of dissatisfaction with work, social life, leisure, and other areas of life, which leads to the need for selfaffirmation due to the weak, unable to fight back and protect themselves (Shatalov \& Moldavanov, 2016).

It is difficult to fight such a psychological phenomenon, but fostering responsibility for one's defeats and developing psychological resilience in future generations is the key to reducing the impact of this factor in the future.

The third factor is the socio-cultural nature of society, an integral part of which are stereotypes about the essence of family relationships, perceived with upbringing, which, for example, is expressed in folklore "beats - means loves." This also includes the regularity between the abuse of relatives and friends in adult life and the personal life experience of a person who witnessed or was a victim of violence as a child.

The solution to this problem in general is already happening through the liberalization of views and wide discussion of these topics in the media. However, it would be good to introduce in educational institutions the basics of family life, the division of responsibilities, and the relationship between family and state.

The fourth factor is the personal negative characteristics of the offender, such as depression, impulsivity, aggression, anxiety, as well as alcoholism and drug addiction or inadequate conflict resolution skills, pathological jealousy, etc.

In contrast, certain characteristics of the victim should also be mentioned, such as constant complaints and grievances, violations of domestic rules and customs, open disrespect, or psychological pressure that has led, for example, to physical violence by another person. 
In this regard, it is necessary to increase the efficiency of care centers, encourage people to visit psychologists, and promote a healthy lifestyle to neutralize these personal negative traits and teach them to live in harmony with themselves and their families.

Separately, it should be noted that in Ukraine there are 21 centers for social and psychological assistance and 8 centers for medical and social rehabilitation of victims of domestic violence, as well as many small private and public charitable organizations at the local level. The most powerful of them is "La Strada Ukraine" which is part of the international organization "La Strada", whose activities are aimed at preventing domestic violence, gender discrimination, human trafficking, and protecting the rights of children. In recent years, thanks to a strong team, the project has managed to cooperate and receive material and informational support from many international, state, and private companies (La Strada Ukraine, 2020).

However, the main problem with all these centers is the territorial concentration in regional centers and a small team. They do not cover small settlements and have low bandwidth. Often it is the physical presence of someone who can help, where you can spend the night or leave things. Therefore, there is a question of building a network of help centers. This can be done either by state forces by putting in order the existing system of social assistance, or by cooperation with existing private and charitable organizations through grants or some kind of outsourcing of state functions.

It is difficult to say which path will be better, so we propose to first hold a national thematic conference for all interested. An effective solution to this problem requires a dialogue between private, charitable, and international organizations on the one hand and representatives of the state on the other.

Having considered the state, trend, and main general factors of domestic violence in Ukraine, it is possible to propose such general social measures to prevent domestic violence as:

- stabilization of socio-economic life in the country as soon as possible;

- active fight against unemployment;

- raising children in the spirit of humanism and responsibility for their actions;

- introduction of the subject in educational institutions, which will provide basic knowledge and patterns of behavior in interpersonal relationships in adult life;

- increasing the efficiency and accessibility of assistance centers; and,

- to encourage the population to visit psychologists and promote a healthy lifestyle at the state level. 


\section{IV.4. Special measures to prevent domestic violence and recommendations for their improvement}

Prevention of domestic violence is a system of social, legal and special measures aimed at eliminating the causes and conditions conducive to committing domestic violence, stopping domestic violence that is being prepared or has already begun, bringing to justice those responsible for committing domestic violence, as well as medical and social rehabilitation of victims of domestic violence. The implementation of these measures is entrusted to the system of interconnected and coordinated state bodies and public associations.

Preventive activity is one of the main directions of both the fight against crime in general and domestic violence in particular. In this activity, two levels or two areas which are social and special criminological are distinguished.

The first direction of crime prevention in the field of domestic violence consists of a set of economic, political, ideological, cultural, educational, legal, and other measures that do not have their immediate goal of eliminating criminogenic factors. They influence indirectly, through the solution of general social problems, ensuring a dignified existence of a person, protection and the possibility of realizing his rights and freedoms.

The second direction is the implementation of a comprehensive mechanism for preventing domestic violence, which is spelled out in section III of the Law on Preventing and Countering Domestic Violence (2017), such a mechanism is spelled out through the following techniques and methods, which can be grouped into:

(i) general constant monitoring of the situation of domestic violence (studying the situation, collecting statistical data, organizing and conducting research in the field of causes, prerequisites for the spread of domestic violence);

(ii) social and educational activities among the population, including among children and young people, conducting information campaigns on the prevention and counteraction of domestic violence (including the introduction of educational programs in educational institutions, the involvement of the media in educational activities); and,

(iii) training activities in the form of training, seminars for specialists who work in the field of preventing and combating domestic violence, as well as for law enforcement officials and court.

The mechanism is clear, specific and, in case of constant implementation, will contribute to the achievement of the set goal. Thanks to the implementation of such a mechanism, society began to talk about the 
phenomenon of domestic violence. Admittedly, this is already a huge step towards solving the problem. In addition, the activities of many public organizations and associations received a legislative basis to carry out educational activities aimed at countering domestic violence in Ukraine. The emergence of various public organizations that are active in social networks, for example White Ribbon Ukraine, one of the organizations that posts useful information where you can contact in cases of domestic violence, psychological information posts, how to identify signs of violence, and more, contributes to the dissemination of useful information, raises global "uncomfortable" questions so that victims of violence "do not keep silent" (White Ribbon Ukraine). Some courts of the city of Odesa, despite the heavy workload and complexity of work in today's realities, also conduct educational and active legal assistance in this direction.

For example, the Public Center of Justice of the Odesa region, which was created on the initiative of the chairman of the Kyiv district court of Odesa, has already consulted about 2073 residents of Odesa for a short time, including on issues of domestic violence (Public center of justice of the Odesa region has consulted about 2073 residents of Odesa, 2020).

The third area of prevention of crimes in the field of domestic violence is a set of special response measures of authorized state bodies, applied to specific individuals, taking into account the individual situation of each case.

Thus, the law "On Preventing and Countering Domestic Violence" (2017), which came into force only in 2019, contains such measures to suppress domestic violence: (i) taking the offender on preventive records and carrying out preventive work with him; (ii) referral of the abuser to a program for perpetrators. (iii) a restrictive injunction against a person who has committed domestic violence; and, (iv) an urgent injunction against a person who has committed domestic violence.

The content of each special event and current problems in their implementation should be revealed.

a) Taking the Offender on Preventive Records and Carrying Out Preventive Work with Him

This action is regulated by the order of the Ministry of Internal Affairs $\mathrm{n}^{\circ} 124$ (2019), which consists in taking the offender on preventive registration, carrying out preventive work with him and removing him from the preventive register. This is done by an authorized subdivision of the body of the National Police of Ukraine (subdivisions of juvenile prevention and the service of district police officers) from the moment of revealing the fact 
of committing domestic violence for up to three years from the moment of the last incident of domestic violence.

This is the mildest measure on the part of law enforcement agencies and, first of all, it is aimed at realizing the seriousness of the offender's position and the possible legal consequences if he continues to unlawful actions, an outside perspective on his behavior in the family. The main problem of this event is that the law enforcement officers themselves do not use it often and try to reconcile the parties on the spot, since the current procedure involves a lot of paperwork without any understandable legal consequences. The solution to this problem consists in the global task of changing the motivation of law enforcement agencies from the "cane system" to alternative indicators - the level of trust on the part of the population, the number of processed applications and the level of satisfaction of the applicant with the work done.

\section{b) Sending the Abuser to a Program for Perpetrators}

Following Art. 39 of the Code of Administrative Offenses (1984), in the situation of domestic violence, the court (when deciding on the imposition of a penalty on an administrative offense) has the right to simultaneously resolve the issue of sending the perpetrator of domestic violence to the program for the offender. The offender who deliberately evades the program for the offenders will incur criminal liability under Art. 390-1 of the Criminal Code of Ukraine. The program itself is set out in a very brief form in the Order of the Ministry of Social Policy n ${ }^{\circ} 1434$ (2018) and is a course on the basics of acceptable social behavior, group, and individual psychotherapy. Its main problem is the lack of a unified methodology for conducting classes, a lack of qualified psychologists and psychiatrists with good pay, a lack of the centers themselves, and their remoteness from many regional centers. It is not uncommon for the abuser to be sent to a rehabilitation program, and the nearest place is only three months later and he just returns home. Naturally, this situation needs to be urgently corrected.

\section{c) Urgent Injunction Against the Abuser}

An urgent restraining order is issued to the offender by authorized units of the National Police of Ukraine (units of juvenile prevention, the service of district police officers and the patrol police) in case of an immediate threat to the life or health of the injured person to immediately stop domestic violence, prevent its continuation or re-committing for up to 10 days. An urgent restraining order may contain the following measures 
(one or all): an obligation to leave the place of residence (stay) of the injured person, a ban on entry and stay at the place of residence (location) of the injured person, a prohibition in any way to contact the injured person.

The form for assessing the commission of domestic violence consists of 27 questions, to which the police officer must answer "yes", "no", "unknown" (On the statement of the Procedure for carrying out an assessment of risks of commission of domestic violence, 2018). The questions relate directly to the safety of the injured person: if the abuser threatened to kill, if the abuser used physical violence, if he caused moderate and/or severe bodily harm, if the abuser has an alcohol or drug addiction, if the abuser has a weapon and/or can easily get it and use the like.

When determining a high level of danger, an urgent prohibition order must be issued to the offender. If a Medium Severity is determined, an urgent restraining order is recommended, but not all of the measures it contains are used. If a low level of danger is determined, then the order is made at the discretion of the police officer.

The high level of danger indicates that if urgent measures are not taken, the next call to the police can result in serious consequences for the injured person. Undoubtedly, in such a situation, the abuser and the injured person cannot be together in the same living space, someone must leave. If the aggressor is at the same time the owner of the living space, then from this moment a serious discussion begins about who should leave - the victim, and the owner should stay, or vice versa, the victim should stay, and the owner should leave. For example, the lawyer Tamara Bugayets (2019) defends an unequivocal position in the spirit of modern radical feminists that the offender must leave: "Now a woman goes, goes with a broken nose, broken ribs, at night, with children, goes to her mother, friend or to a specialized center, but the abuser has to go. This is a world practice. There is no question of violation of the right to housing at all because the protection of the right to life and health is in the first place."

However, we believe this approach only harms the real victims of violence, because if there is a material interest on the part of the victim, one should expect a wave of fraudulent actions when the "victim" becomes the aggressor and is capable of slandering or at least embellishing the conflict that has occurred. It is very difficult for the police on the spot to figure out who is to blame and who is not, and their primary task is to prevent new violence. Such a policy of identifying the perpetrators and issuing punishments on the spot will inevitably lead to rejection by conservative circles, human rights organizations, and a devaluation of real cases of domestic violence. It is worth sacrificing the rights of one person for the 
rights of another only thoroughly, having understood the situation, and only by a court decision.

Thus, any calls that suggest sacrificing freedom of speech and private property to protect various victims, we regard as unconstitutional. We have enough mechanisms to ensure the protection of human rights and freedoms within the framework of the Constitution. The Ukrainian people have already endured enough under the rule of communist fighters for the rights of workers and are very skeptical about modern left-liberal political tendencies.

Resolving the issue with housing we see the solution to this issue in the development and optimization of the network of state and private aid centers, raising the level of their material and technical support and providing the necessary personnel. Sometimes there is an opinion that the state has no funds, we do not support, because, firstly, on a national scale we are talking about insignificant amounts, and secondly, the more coverage of this topic, the more chances to attract the attention of state and municipal politicians, overseas charities and local private investors. The main thing is that the infrastructure is in place, it needs to be put in order.

\section{d) Restrictive Injunction against the Offender}

The Code of Civil Procedure (2004) was supplemented by ch. 13 "Consideration by the court of cases on issuance and extension of restrictive instructions". A restrictive order defines one or more of the following measures of temporary restriction of the rights of the offender or imposition of obligations on him:

- prohibition to be in the place of joint residence (stay) with the injured person

- elimination of obstacles in the use of property that is the object of the right of joint ownership or personal private property of the victim;

- restriction of communication with the injured child;

- prohibition to approach at a certain distance to the place of residence (stay), study, work, other places of frequent visits by the victim;

- prohibition to search for the injured person personally and through third parties, if he/she is in a place unknown to the offender, to persecute him/her and to communicate with him/her in any way; and,

- prohibition of correspondence, telephone conversations with the victim or contact with him through other means of communication personally and through third parties. 
Relevant restrictive instructions may be issued by a court for up to 6 months. However, according to the judges, there are formal risks in the process of considering an application for a restraining order. First of all, this is the application review time of 72 hours. During this time, the addresses of the parties must be verified, the parties must be duly notified, the necessary evidence must be requested, all evidence must be assessed, and the merits of the decision must be rendered. Often in such a period, all these actions are unlikely to be carried out at the proper level, especially during a pandemic. In practice, a situation has developed where the victim must start collecting all evidence before filing a complaint, although in this case, her ability to collect evidence is limited since law enforcement agencies have the right to intervene only after filing a complaint. The solution to this problem is possible in increasing the possible period of consideration of the application or the creation of two procedural stages - the collection of evidence and the period of consideration of the application after all documents have been submitted. It also seems reasonable to expand the list of using videoconferencing in court hearings and legal proceedings as much as possible without violating the rights of the parties.

The emerging practice in court is also interesting, when most attention is paid to the following issues:

- whether there was a violation of the right within the European Court of Human Rights;

- on what grounds can one say that a person is a victim of domestic violence;

- what was the form of domestic violence;

- what is the causal relationship between the act and the effect;

- what consequences have occurred for the affected person or may occur in the future;

- whether the victim contacted various services (police, social services, support services, community organizations) and what was their reaction;

- whether the police persuaded to withdraw the statement of violence;

- what is the likelihood that domestic violence may recur;

- proportionality of the measures requested by the injured person; and,

- if there is a child in the family, then it is imperative to find out his opinion (Grytsenko, 2019).

Knowledge of the peculiarities of consideration of such cases by the parties and their lawyers will allow them to better protect their rights and freedoms. Hopefully in the future the Supreme Court will issue the appropriate recommendations at the official level. 
A brief overview of the existing special measures for the prevention of domestic violence allows us to say that even though they are a rather large step in the possibilities of legal protection compared to what it was several years ago, today some nuances and details need to be settled in within the framework of bylaws. The next important problem is insufficient attention and funding from the state of infrastructure, personnel and projects within the framework of the public institution for the protection of victims of domestic violence. And the surge in domestic violence during the pandemic should serve as an early catalyst for reforms in this area.

\section{CONCLUSIONS}

In the process of scientific research, the goal was set to structurally present the problems of domestic violence during the Covid19 period. The problematic was studied through the evolution of human rights to life without violence, international treaties and domestic specifics of legal regulation, practical experience and developments of the scientific community. Such an analysis made it possible to draw the following important conclusions

1. First of all, the international legal framework and reforms of domestic legislation in recent years were studied. The issue of preventing domestic violence turned out to be partly political and caused different reactions in different countries. Ukraine belongs to the countries that have not yet ratified the Istanbul Convention, but there are consistent steps on the part of the legislator in this direction.

2. The new 2017 law on the prevention of violence is quite progressive, however, the imperfection of by-laws and departmental instructions hinder its full implementation.

3. Covid-19 has become a catalyst for domestic violence around the world, and according to the above statistics, Ukrainian society is no exception. The consequence of such a wave of violence, together with other socio-economic shocks, was an increase in mortality, a drop in living standards, the destruction of family institutions, and many people in a difficult economic and psychological situation.

4. The latency of domestic violence and its transformation during a pandemic is revealed. Gradually, people are talking about this more and more openly, but the involvement of law enforcement agencies is also fraught with several difficulties.

5. The global factors of domestic violence and synergistic effect with the pandemic are considered, which led to such a wave of domestic violence. 
Emergency solutions are proposed at the state level through the stabilization of the socio-economic situation of the population, an active fight against unemployment, the development of special centers for assistance to victims of domestic violence.

6. The review of special measures to prevent domestic violence allows us to say that even though they are a rather large step in the possibilities of legal protection compared to what it was a few years ago, today there are many omissions, starting with outrageous attempts to limit property rights ending with an insufficient period of application for the issuance of a restrictive order, which prevents the full realization of the rights of victims of violence.

7. A low assessment was given to the direct side of the implementation of state policy in the field of violence prevention, which is associated with a variety of problems on the ground, from the "cane system" of assessing the activities of law enforcement agencies to critically low funding for victim assistance centers and centers for the rehabilitation of aggressors, which negates efforts to combat violence to the application of criminal liability. It was proposed to hold a national conference to build a dialogue and effectively solve this problem between private, charitable and international organizations on the one hand and government representatives on the other.

8. Only a decisive set of actions on the part of the state, law enforcement agencies, public organizations and the whole society on the problems identified in the article and possible ways to solve them can minimize the nationwide harm from the wave of domestic violence that we faced as a result of the Covid-19 pandemic.

\section{REFERENCES}

Abueish, T. (2020). Coronavirus: A Jordanian woman pleads for help as domestic abuse cases rise globally. Al Arabiya English. In https://english.alarabiya.net/en/features/2020/04/06/Coronavirus-Jordanianwoman-s-pleas-for-help-highlight-global-rise-of-domestic-abuse.html.

Alekseeva, J. (2018). Istanbul Convention: Spiritual Dimension. In http://www.pravoslavie.ru/.

Areshev, A. (2019). Armenia: Will the "Istanbul Convention" Be Ratified? Voice of Armenia. In https://www.golosarmenii.am/article/85002/armeniya-budet-liratificirovana-stambulskaya-konvenciya.

Bugayets, T. (2019). Domestic violence: focus on hard skills. Legal newspaper online. In https://yur-gazeta.com/publications/practice/kriminalne-pravo-taproces/domashne-nasilstvo-fokus-na-hard-skills.html. 
Burgen, S. (2020). Three women killed in Spain as coronavirus lockdown sees rise in domestic violence. The Guardian. In https://www.theguardian.com/globaldevelopment/2020/apr/28/three-women-killed-in-spain-as-coronaviruslockdown-sees-rise-in-domestic-violence.

Council of Europe. (2011). Detailed information about Treaty $n^{\circ} 210$ Council of Europe Convention on Preventing and Combating Violence against Women and Domestic Violence. In https://www.coe.int/ru/web/conventions/full-list//conventions/treaty/210.

Council of Europe. (2011). On preventing and combating violence against women and domestic violence (Istanbul Convention). In http://docs.cntd.ru/document/420206767.

Grytsenko, L. (2019). Materials of the training seminar "Domestic Violence: Peculiarities of Victim Representation”. In http://tomorrowslawyer.org/event/семінартренінг-домашнє-насильство/.

Istanbul Convention: what is written in the controversial document? (2016). In https://www.grani.lv/latvia/68218-stambulskaya-konvenciya-chto-napisano-vskandalnom-dokumente.html.

Janetsky, M. (2020). Violence against women up amid Latin America Covid-19 lockdowns. In https://www.aljazeera.com/indepth/features/violence-womensurges-latam-coronavirus-quarantines-200420020748668.html

Johnson, K. (2020). Covid-19 coronavirus: Domestic violence is the second, silent epidemic amid lockdown. NZ Herald. In https://www.nzherald.co.nz/nz/news/article.cfm?c_id=1\&objectid=12324237.

Kaczynska, M. (2016). Causes of latency of domestic violence. Journal of Eastern European Law, 33, 27-32. In http://easternlaw.com.ua/wpcontent/uploads/2016/11/kachynska_33.pdf.

La Strada Ukraine. (2020). Our donors and partners. In https://la-strada.org.ua/donory.

Lauvergnier, C. (2020). Lockdown in Colombia leads to spike in domestic violence.

Observers. In https://observers.france24.com/en/20200706-colombia-domesticviolence-lockdown-covid-19-women.

Lesko, N. (2019). Administrative and legal support for the formation and implementation of state policy in the field of protecting children from violence and other illegal actions. Lviv: NU Lviv Politex. In https://lpnu.ua/sites/default/files/dissertation/2019/12148/dysertaciya_na_zdobu ttya_naukovogo_stupenya_doktora_yurydychnyh_nauk_lesko_nataliyi_volody myrivny.pdf.

Nikiforova, V. (2020). Coronavirus has brought thousands of "deaths of despair" to the West. Look: business newspaper. In https://vz.ru/world/2020/5/29/1041813.html.

Numbeo. Europe. (2020). Crime Index by Country 2020 Mid-Year. In https://www.numbeo.com/crime/rankings_by_country.jsp?title=2020mid\&region $=150$. 
Osipyan, N.B. (2012). Female violence against men: an analysis of foreign and domestic research. North Caucasian psychological bulletin, 10(4), 42-46. In https://cyberleninka.ru/article/n/zhenskoe-nasilie-v-otnoshenii-muzhchinanaliz-zarubezhnyh-i-otechestvennyh-issledovaniy.

Public center of justice of the Odesa region has consulted about 2073 residents of Odesa. (2020). I and the Law. In https://yaizakon.com.ua/obshhestvennyj-tsentrpravosudiya-prokonsultiroval-2073-odessitov/.

Romantseva, S. (2018). Prevention of sexual violence against children in Ukraine. Lviv: NU Lviv Politex. In https://lpnu.ua/sites/default/files/dissertation/2018/10869/aref_mukan_o.v._rom ancova.pdf.

Shatalov, E. \& Moldavanov, K. (2016). Youth crime and the main directions of countering it. Moscow: Prospect Publishing House.

Skolovskaya, Y. (2020). Every 5th woman in Ukraine faces some form of violence. Ministry of Social Policy of Ukraine. In https://www.msp.gov.ua/news/18311.html.

Strizhak, O. (2020). Every year more than 1.8 million Ukrainian women suffer from domestic violence. Ukrinform. In https://www.ukrinform.ua/rubricculture/2588861-soroku-ponad-18-miljona-ukrainok-poterpaut-cerez-domasnenasilstvo.html.

Timko. S.A. \&, Kuznetsova, I. (2017). Female Violence against Spouses: Features of Manifestation and Opportunities for Prevention by Internal Affairs Bodies of Ukraine. Psychopedagogy in law enforcement bodies, 4(71), 50-54. In https://cyberleninka.ru/article/n/zhenskoe-nasilie-v-otnoshenii-suprugovosobennosti-proyavleniya-i-vozmozhnosti-profilaktiki-organami-vnutrennihdel.

Tkalenko, O.M. (2016). Administrative-legal regulation ensuring the activities of public administration bodies to prevent domestic violence against children. Odesa: Phoenix. In http://oduvs.edu.ua/wp-content/uploads/2016/09/dus_tkalenko.pdf.

Tomusyakova, I. (2014). International Legal Acts Regulating Counteraction to Domestic Violence. Forum of law, 2, 438-441. In http://www.pravnuk.info/fomumpr/1634-mezhdunarodnye-pravovye-akty-reguliruyushhie-protivodejstvienasiliyu-v-seme.html.

Ukraine. (1984). Code on Administrative Offenses. In https://zakon.rada.gov.ua/laws/show/80731-10\#Text.

Ukraine. (2001). Criminal Code. In https://zakon.rada.gov.ua/laws/main/2341-14.

Ukraine. (2001). On the Prevention of Domestic Violence: Law. In https://zakon.rada.gov.ua/laws/show/2789-14.

Ukraine. (2004). Civil Procedure Code. In https://zakon.rada.gov.ua/laws/show/1618$15 \#$ Text.

Ukraine. (2017). On Preventing and Countering Domestic Violence: Law. In https://zakon.rada.gov.ua/laws/show/2229-19. 
Ukraine. Cabinet of Ministers of Ukraine. (2016). On the statement of the State target social program: Decree 148. In https://zakon.rada.gov.ua/laws/show/148-2016п\#n11.

Ukraine. Ministry of Education and Science of Ukraine. (2018). Guidelines for preventing and combating violence: Letter $\mathrm{n}^{\circ} 1 / 11-5480$. In https://imzo.gov.ua/2018/05/21/lyst-mon-vid-18-05-2018-1-11-5480metodychni-rekomendatsiji-schodo-zapobihannya-ta-protydiji-nasylstvu/.

Ukraine. Ministry of Internal Affairs of Ukraine. (2019). On approval of the Procedure for registration, preventive work and deregistration of the offender by an authorized unit of the National Police of Ukraine: Order $n^{\circ} 124$. In https://zakon.rada.gov.ua/laws/show/z0270-19\#Text.

Ukraine. Ministry of Social Policy and Ministry of Internal Affairs. (2018). On the statement of the Procedure for carrying out an assessment of risks of commission of domestic violence: Order $\mathrm{n}^{\circ} 369 / 180$. In http://search.ligazakon.ua/1_doc2.nsf/link1/an/62/RE33304.html\#62.

Ukraine. Ministry of Social Policy. (2018). On approval of the Standard program for offenders: Order $\mathrm{n}^{\circ}$ 1434. In https://zakon.rada.gov.ua/laws/show/z122218\#Text.

United Nations (1993). Declaration on the Elimination of Violence against Women. In https://zakon.rada.gov.ua/laws/show/995_506.

United Nations calls on the Verkhovna Rada to ratify the Istanbul Convention. (2020). I and the Law. In https://yaizakon.com.ua/oon-prizyvaet-ukrainu-srochnoratifitsirovat-konventsiyu-kotoraya-zashhishhaet-prava-zhenshhin/.

United Nations chief calls for domestic violence "ceasefire" amid "horrifying global surge”. (2020). UN News. In https://news.un.org/en/story/2020/04/1061052.

United Nations General Assembly. (1996). Model Legislation on Domestic Violence: Resolution. In http://www.owl.ru/win/books/nasilie/pril_vi.htm.

Universal Declaration of Human Rights. (1948). In https://zakon.rada.gov.ua/laws/show/995_015.

Wanqing, Z. (2020). Domestic Violence Cases Surge during Covid-19 Epidemic. Sixth Tone. In https://www.sixthtone.com/news/1005253/domestic-violence-casessurge-during-covid-19-epidemic.

White Ribbon Ukraine. Official Facebook page. In https://www.facebook.com/whiteribbonukraine/.

World Health Organization (2017). Violence against Women. In https://www.who.int/ru/news-room/fact-sheets/detail/violence-against-women.

Yavoroska, T. (2020). Domestic violence in quarantine: how to avoid. In https://dyvys.info/2020/03/25/domashnye-nasylstvo-v-umovah-karantynu-yakunyknuty/. 